\title{
The Bankruptcy Reform Act Of 2005
}

Tom Moore, (Email: Tom.Moore@gcsu.edu), Georgia College And State University

\begin{abstract}
The new changes in the Bankruptcy Code make it significantly more difficult for a debtor to eliminate his obligations under Chapter 7. Many filers will be required to pay some or all of their unsecured debts for a five year period by being forced into Chapter 13. The Act also makes other modifications to filing requirements, exemption changes, and non-dischargeable debts which also tend to favor the creditor. The changes make filing for Bankruptcy more expensive and may reduce the number of cases.
\end{abstract}

\section{INTRODUCTION}

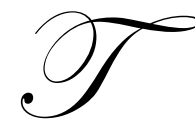

he Bankruptcy Abuse Prevention and Consumer Protection Act of 2005 (the Act) is the first major revision of Bankruptcy Law since 1978. For most bankruptcy filings after October 17, 2005, the Act now reduces the benefits that debtors had in the past. Filing for bankruptcy protection is now more expensive, difficult, and offers fewer advantages to debtors than did the prior rules. The purpose of this paper is to discuss some of the major changes the Act has made in debtor-creditor relations and seeks to explain the probable implications of these changes to debtors.

\section{CREDIT COUNSELING REQUIREMENT}

Under Section 106 of the Act, before an individual can file a petition under Chapter 7 (Liquidation) or Chapter 13 (Wage Earner Plan), the petitioner must have received credit counseling from a source approved by the Bankruptcy Trustee. The counseling must be done within 180 days before the debtor files his petition. The counseling is not required to be conducted in-person and may be done over the telephone or the through the internet. Although the exact content of the counseling is not specified by the Act, it is expected that the creditor will receive information about the alternatives to bankruptcy as well as its economic effects. The creditor will receive a document certifying he has received the counseling and must file this paper with his petition.

\section{Likely Outcomes}

Consumer counseling was not required under the old rules. It is expected that a variety of for-hire companies and agencies will develop to service the debtor's requirement for the mandated information. Fees charged by these companies will increase the costs of bankruptcy for the filer and the information provided may also persuade certain debtors not to file thereby reducing the number of petitions.

\section{BANKRUPTCY ATTORNEYS}

Under Section 102 of the Act, Attorneys who practice Bankruptcy Law are also affected by the Act. The attorney, who files a petition on the behalf of a client, must conduct a "reasonable inquiry" and investigation before filing. The attorney is civilly liable for filing a false petition if he has not exercised this due diligence. In effect, the attorney is certifying the means test now required for a Chapter 7 filing. Attorneys who solicit clients through advertisements must disclose in the ads that they, in fact, file bankruptcy petitions and do not just consolidate debts for their clients. 


\section{Likely Outcomes}

Since attorneys will be liable for filing false petitions, fewer attorneys will continue doing Bankruptcy work. The fees for those who remain will undoubtedly increase. Attorneys may favor Chapter 13 filings over Chapter 7 to reduce their potential liability for improper filings. To protect themselves, lawyers will now require clients to furnish them with lengthy financial records, tax information, and credit reports before they will represent them in Bankruptcy Court. Also, many lawyers will likely have to change their advertisements.

\section{CONTENTS OF BANKRUPTCY FILINGS}

Section 316 of the Act adds requirements to the creditor's initial Bankruptcy filings. In addition to a detailed list of assets, liabilities, income, and the counseling certificate, creditors must now inform the Bankruptcy Court if additional income from other sources, such as family gifts, is expected in the following year. If all the required forms are not filed within 45 days from the date of the initial filing, the case can be dismissed. Debtors will now also have to file income tax returns and make these available to creditors.

\section{Likely Outcomes}

With the additional filing requirements, some creditors will inadvertently have their case dismissed by failing to file all the required documents. This dismissal may impact the automatic stay provision. The provision allowing creditors access to a petitioner's income tax returns is new.

\section{MULTIPLE FILINGS}

Section 312 of the new law requires an eight year waiting period before one previously adjudicated bankrupt under Chapter 7 can file another Chapter 7 action. The old rule allowed a re-filing of a Chapter 7 petition after a six year period. Also, the Act requires that a debtor who has been discharged under Chapter 7 must wait a minimum of four years before filing under Chapter 13.

If the debtor's original petition is dismissed and he re-files it within one year, the automatic stay is only in effect for 30 days under Section 302. If a second petition is dismissed and later re-filed within the same year, the automatic stay is not triggered. Also, in any event, the automatic stay is never effective against actions to enforce support agreements including alimony or child support under the new Section 214.

\section{Likely Outcomes}

The required four year waiting period between a Chapter 7 and a subsequent Chapter 13 filing will prevent the common practice of debtors filing a Chapter 7 (to eliminate all unsecured debt) and then immediately filing a Chapter 13 (to give them extended time to deal with any delinquent interest and past due amounts on secured obligations). Furthermore, creditors are now forced to file all required documents with their original petition. Typically, courts have dismissed improperly filed petitions and creditors have been able to re-file without penalty. Now, a repeat filing will result in some of the benefits of the automatic stay being lost by the creditor.

\section{FORCED CONVERSION OF CHAPTER 7 CASES INTO CHAPTER 13}

The old rules allowed a quick elimination of most debts under Chapter 7. Chapter 13, which requires a debtor to repay a portion of their debt over a period of time, was useful when the taxpayer had non-exempt property that creditors may have been able to garner if Chapter 7 had been filed. Under the Act, the Bankruptcy Court will now convert many Chapter 7 cases into Chapter 13. Chapter 7 cases will only be allowed if the debtor's income falls below certain levels.

Under Section 102, the new means formula applies to a debtor who files under Chapter 7. It involves a multi-step calculation. First, the debtor's average monthly income for the six months preceding the filing is calculated. 
The calculation includes both taxable and non-taxable income and also includes a non-filing spouse's income. If this amount is less than the state median, then a Chapter 7 filing is permitted. If this amount is more than the state median, then the individual's income that remains available to creditors (disposable income) is calculated. The calculation requires average monthly expenses to be subtracted from monthly income. The monthly expenses are determined based on the area of the country where the debtor resides and includes factors such as family size. The expenses are extracted from tables the Internal Revenue Service uses when it attempts to obtain delinquent taxes. The monthly disposable income is then multiplied by 60 months. If the amount calculated is over $\$ 10,000$ the individual will have his case converted into a Chapter 7. If this amount is below $\$ 10,000$, but is greater than the larger of $\$ 6000$ or $25 \%$ of the total unsecured debt, the case will also be converted. If the disposable income available over five years is less than the greater of $\$ 6000$ or $25 \%$ of the unsecured debt, the debtor is entitled to continue with Chapter 7 . These rules are best illustrated by the following four examples:

- Debtor, a single individual, files a Chapter 7 petition in the state of Georgia. Debtor's total income is less than the median income for a single individual living in Georgia. Debtor is allowed to continue in Chapter 7.

- Debtor, a single individual files a Chapter 7 petition in the state of Georgia. Debtors average monthly income $(\$ 3,000$, for instance) is greater than the state average. Assume the allowed reasonable expenses from the IRS's tables for a single individual living in his county in the State of Georgia is $\$ 2500$ per month. This gives him disposable income $\$ 500$ per month x 60 months or $\$ 30,000$. Since this exceeds the $\$ 10,000$ limit, his filing is converted into Chapter 13. His excess disposable income will be paid to his creditors over the next 5 years.

- $\quad$ Debtor, a single individual files a Chapter 7 petition in the state of Georgia. Debtors average monthly income (\$2650, for instance) is still greater than the state average of $\$ 2500$. Disposable income is now $\$ 150$ per month x 60 months or $\$ 9000$. Debtor has total unsecured debts of $\$ 12,000$. Since the debtors disposable income ( $\$ 9000$ ) is greater than $\$ 6000$ (which is the larger of $\$ 6000$ or $25 \%$ of the unsecured debts), the petitioner will be forced into Chapter 13.

- Debtor, a single individual files a Chapter 7 petition in the state of Georgia. Debtors average monthly income ( $\$ 2650$, for instance) is still greater than the state average of $\$ 2500$. Disposable income is now $\$ 150$ per month x 60 months or $\$ 9000$. Debtor has total unsecured debts of $\$ 40,000$. Since the debtors disposable income (\$9000) is less than $\$ 10,000$ (the larger of $\$ 6000$ or $25 \%$ of the unsecured debts), the debtor will be allowed an immediate discharge under Chapter 7.

\section{Likely Outcomes}

The immediate elimination of debts under Chapter 7 will only be available for individuals with lower incomes. The Census and the Federal Bankruptcy Trustee are expected to publish schedules of acceptable expenses on their websites. Many filers will be required to repay their creditors some monies for a five year period. This impact may also serve to lessen the effectiveness of bankruptcy law and result in fewer filings and more wage garnishments and repossessions. However, creditors may be more likely to make credit available to higher income individuals and small business owners since the creditor is now likely to recover at least some of their loaned funds even it the debtor later bankrupts. Also, individuals who have good credit scores may now enjoy lower interest on loans and credit cards since creditors will now not have to write off as many bad accounts.

\section{DOMICILE FOR HOME EXCLUSIONS}

Individuals can elect to use the list of exemptions under the Federal Bankruptcy list or the state in which they are domiciled in. Under Sections 307 and 322 of the Act, petitioners must now live in a state for at least 730 days before they are eligible for the state list. The old rule required them to live in the state for only six months before the filing of the petition. In regard to homes, the maximum limit that can be shielded from creditors in any state is limited to the first $\$ 125,000$ if the home has been purchased within the past 1215 days unless a resident has rolled over the proceeds of a home located in the same state into the new home. Also, the creditor can not shield assets in a homestead from creditors (beyond the $\$ 125,000$ limit) if the judgments are based on his violation of state or federal Securities law, RICO violations, or intentional physical injuries he inflicted on another. 


\section{Likely Outcomes}

Previous bankruptcy rules allowed wealthy individuals to move to certain states and receive the benefit on an unlimited homestead exemption. The debtor would buy a luxury home and then file his bankruptcy petition. Creditors would not be able to garner the home's equity. Florida and Texas are two states which have this generous exemption. Now, unless the debtor has owned a home in these states for over 1215 days, equity in the home can no longer be shielded above the $\$ 125,000$ exclusion. Also, even in Florida or Texas, a corporate executive who engineers an accounting scandal and is convicted with SEC violations can no longer declare bankruptcy and keep a mansion.

\section{LANDLORDS AND TENANTS}

Under Section 311 of the Act, if a landlord obtains a court order evicting a tenant and subsequently, the tenant files a bankruptcy petition, the automatic stay does not apply and the landlord can still evict the tenant. Even if the tenant is current with his rent, the landlord can still evict during the bankruptcy proceedings if the tenant has placed the property in endangerment or the tenant is using the property to house illegal controlled substances.

\section{Likely Outcomes}

Landlords will go to court earlier now to obtain dispossessory orders when tenants are behind on their rent. If the order is obtained before the filing of bankruptcy, the tenant can be evicted even while the case is pending.

\section{CREDIT CARD/CASH ADVANCES/STUDENT LOANS}

Section 310 of the Act provides that a petitioner in Bankruptcy will still have to repay any charges to a credit card made within 90 days prior of the filing of the petition if the debt is for luxury goods which cost at least $\$ 500$. The old standard required purchases totaling at least $\$ 1225$. For cash advances, the limits are $\$ 750$ and the time limit is shortened to withdrawals made within 70 days prior to filing. Student loans are now non-dischargeable, even if the lender is a non-governmental private under Section 220.

\section{Likely Outcomes}

Debtors will no longer be able to "max-out" their credit cards shortly before bankruptcy and escape responsibility. Filings may be delayed until after 90 days after the charges are made to the accounts. Student loans of any type can only be discharged if the debtor can show that required repayments would constitute an undue hardship. This standard can usually only be met in cases of severe physical disability.

\section{EDUCATION SAVINGS ACCOUNTS/401(K)/PENSIONS}

Section 224 of the Act, like prior law, still protects the first $\$ 1,000,000$ a debtor has in a retirement account from creditors. Also, the debtor's repayments of loans from his retirement account do not count against disposable income in a Chapter 13 filing. Education Savings Accounts are also exempted if the contributions were made at least two years prior to the petition being filed. Only the first $\$ 5000$ of new money is protected if placed into the account between one and two years prior to the bankruptcy. To be protected from creditors, the education account can not list the debtor as the targeted beneficiary of the funds.

\section{Likely Outcomes}

For all but the very wealthy, retirement accounts will remain safe from creditors. Large contributions to these funds may replace the luxury home as the next bankruptcy loophole. Education accounts may also become more popular as a method of saving large quantities of protected money for the education of the debtor's children. 


\section{AUTOS LOANS}

Under prior law a debtor was able to petition under Bankruptcy and only have to pay the secured portion of his loan in order to retain his vehicle. For example, if the debtor owed $\$ 10,000$ on the auto loan and declared bankruptcy when the car was worth $\$ 6000$, the debtor would only be required to pay $\$ 6000$. Section 306 of the Act now requires the debtor to pay the full amount of the claim, both secured and unsecured, in order to reaffirm the loan and keep the vehicle. The provision applies only to autos purchased within 910 days from the filing of the petition.

\section{Likely Outcomes}

A great advantage under the old rule was that it allowed debtors to redeem their goods by only paying the fair market value of the good at the time of Bankruptcy. Since most autos depreciate faster than they are paid for, this created a method where a bankrupt could retain his auto under very favorable economic terms. Now, under the Act, this advantage is lost and the cost of retaining the vehicle increases.

\section{PRIORITY PAYMENTS}

In Chapter 7 filings, the debtor's obligation for support payments for alimony and child support is now paid before any other non-secured debt at liquidation under Section 212. Also, any unpaid wages that the debtor owes previous employees is not increased to $\$ 10,000$ per claim.

\section{Likely outcomes}

Alimony and child support payments are still non-dischargeable debts. However, they now are elevated over consumer credit claims and any unpaid wages owed to former employees by the debtor as a priority item.

\section{DISCHARGE UNDER CHAPTER 13}

Under the old rules, Chapter 13 acted to discharge many more types of debts than did Chapter 7 . Section 314 of the Act now eliminates discharge under Chapter 13 for such things as old taxes, debts owed to creditors based on the debtor's fraud, education loans owed to private lenders, and judgments owed by the debtor based on willful injury to an individual or an injury that occurred while the petitioner was driving while intoxicated. Also, certain criminal fines are no longer discharged. Chapter 13 still serves as a device to discharge willful injury to the property of another or any debt incurred to pay taxes.

\section{Likely Outcomes}

The Act prevents the previous practice of filing under Chapter 7 to eliminate most debts and then re-filing under Chapter 13 to eliminate the debts not covered under the Chapter 7 filing.

\section{CONCLUSION}

Congress, in its attempt to reduce the abuse that occurred under the previous Bankruptcy rules, has made sweeping changes to the debtor-creditor relationship. By implementing this Act, creditors will likely recover more of their claims due to the forced conversion of Chapter 7 cases into Chapter 13. Bankruptcy loopholes are closed, filing requirements are strengthened, and many debts are no longer dischargeable. The debtor's costs of hiring a bankruptcy attorney will increase and the number of Bankruptcy cases may significantly decline. 


\section{ENDNOTES}

1. The full text of the Bankruptcy Abuse Prevention and Consumer Protection Act of 2005 can be found at: http://thomas.loc.gov/cgi-bin/query/D?c109:12:./temp/ c109Gp210j

2. The median income for each state is available at:

http://www.census.gov/hhes/www/income/medincsizeandstate.html

\section{NOTES}

